\title{
A Systematic Review on Students' Engagement in Classroom: Indicators, Challenges and Computational Techniques
}

\author{
Latha Subramainan ${ }^{1}$, Moamin A. Mahmoud ${ }^{2}$ \\ College of Computing and Informatics \\ Universiti Tenaga Nasional \\ Kajang, Malaysia
}

\begin{abstract}
Students' engagement in a classroom is a key factor that influences several educational outcomes. Studies by the University of California, Los Angeles (UCLA) and British universities found that $40 \%$ of students are frequently experiencing boredom and less than $20 \%$ of students ask questions in class due to poor engagement. A survey by Malaysia's Program for International Student Assessment (PISA) found that $80 \%$ of the participating schools fell into the poor performance bracket. However, studies in this line of research are limited and scattered. To provide a clear insight into this problem and support researchers, it is crucial to understand the current state of research in this area. Consequently, in this paper, a comprehensive review is conducted to map the literature studies to a consistent taxonomy. Search terms revealed 87 papers from several databases that have been classified into seven categories. A systematic review method is applied, analysis is performed, and finally, findings, discussion, and recommendations are presented.
\end{abstract}

Keywords-Classroom interaction; student engagement; engagement indicators; engagement challenges; computational techniques

\section{INTRODUCTION}

Over two decades, studies have reported that students' engagement is a crucial factor in predicting students' academic achievement and influencing several educational outcomes [1] [2] [3]. Several factors have been utilized by researcher to indicate engagement such as "self-report, attendance rates, teacher ratings, interviews, observations, cross-cultural data and assessments grades" [4] [5] [6]. On the other hand, researchers measure engagement by observing a student's active participation such as the amount of effort and positive emotion or via a student's voice and initiative to take personal responsibility for his/her behavior [6].

In this paper, we review the literature on students' engagement in a classroom. Search terms identified 87 papers from several databases such as Science Direct, Taylor and Francis, Sage, Springer, Wiley Online, IEEE Xplore. The collection of the selected papers is classified into seven categories, overview; dimensions and indications; research studies; problems; factors influence engagement; methods to measure engagement; and techniques to improve engagement. This paper starts by describing the method used to conduct this review. The method includes a search strategy, search terms, and selection process. We then review the seven categories. We also conduct a comprehensive analysis on the reviewed articles, which include data analysis on students' engagement research, number of selected articles by year of publication, rate of the reviewed articles in different categories, number of articles in different categories by year of publication, and taxonomy of the literature on student engagement. Three potential research problems are discussed, examining the impact of emotion on students' engagement; development of a configuration framework to generate an engagement strategy for a particular classroom environment; utilizing computer-based simulation and virtual environment to study and investigate poor engagement instead of using traditional research tools.

\section{METHOD}

\section{A. Search Strategy}

Six digital libraries and databases are selected to search for papers which are: "Web of Science, SagePub, IEEE Xplore, Springer, ACM Digital Library and Science Direct". The selection in this review includes those identified as relevant to school education, information technology, and social science.

\section{B. Search Terms}

The review aims to find all primary research work in conjunction with the terms for possible outcomes. The relevant search terms in the context of this review are identified as follows: "student-engagement in a classroom"; "student engagement in a classroom"; "student-involvement in a classroom"; "student involvement in a classroom"; "studentparticipation in a classroom"; "student participation in a classroom". Added to these terms are the keywords, "overview"; "research"; "studies"; "methods"; "status", "indications"; "problems".

\section{Paper Selection Process}

The following shows the stages of the selection process:

1) Search based on the search string.

2) Query (as discussed in Section 3.2).

3) Excluding duplicates/non-English articles.

4) Perform an abstract scan and exclude publications that do not address engagement research.

5) Full-text reading to filter and produce final set. 
Using these conditions, 87 papers met the inclusion and exclusion criteria and are identified as relevant to the current review. These papers are classified into the following categories: an overview of students' engagement; dimensions and indications of students' engagement; studies conducted on students' engagement research; problems in students' engagement; factors influence students' engagement; methods to measure students' engagement; and techniques to improve students' engagement.

\section{ANALYSIS AND FINDINGS}

During the analysis, we found 87 papers on students' engagement research. As shown in Fig. 2, nine papers on definition and history of students' engagement, 12 papers on dimensions of students' engagement, 13 papers on studies conducted on students' engagement research, 17 papers on problems in students' engagement, 10 papers on factors influence students' engagement, five papers on methods to measure students' engagement, and 21 papers on techniques to improve students' engagement.

Fig. 1 shows the number of reviewed articles in the seven categories according to the years of publication. The distribution from 1984 to 2018 is shown. The figure shows that, according to the reviewed articles, a few studies have been conducted between 1984 and 2003 at a rate of $12 \%$ of total reviewed papers. In the next five years, the rate increased to $21 \%$. In the last decade, the rate reached $67 \%$. This clearly shows that research in students' engagement is receiving increasing attention.

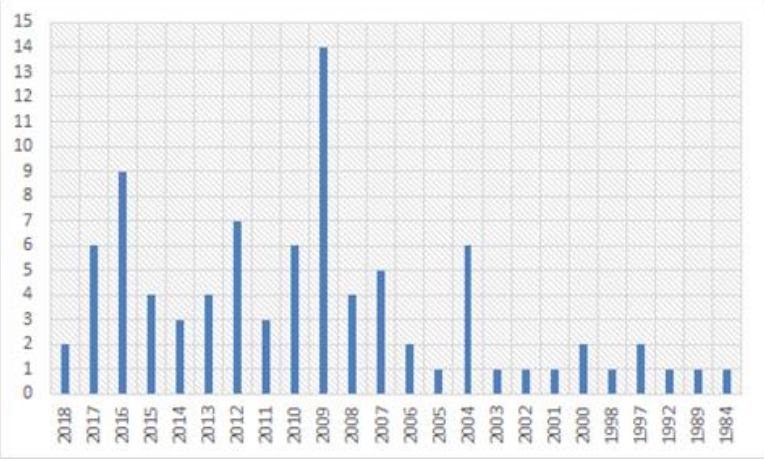

Fig. 1. Number of Selected Articles by Year of Publication.

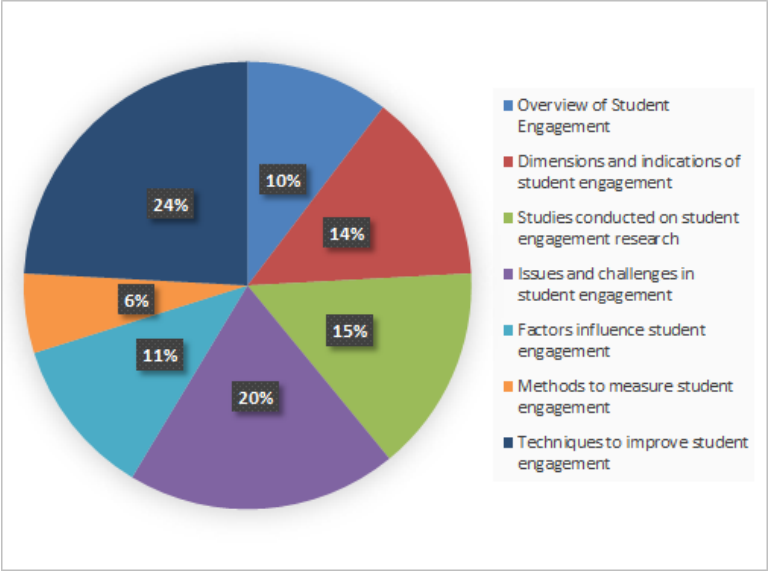

Fig. 2. Rate of the Reviewed Articles in different Categories.
Fig. 3 shows the identity of the source databases of the reviewed articles. Most of the selected articles are from Science Direct, Taylor and Francis, Sage, Springer, Wiley Online, IEEE Xplore, and IGI global, which constitute about $72 \%$ of the selected articles. Some other supporting articles have been selected from other databases.

Fig. 4 shows the number of articles in each category and according to the year of publication. Again, the results show that most of the recently published articles are about the category "techniques to improve student engagement", which clearly reflects that the problem of poor engagement is gaining more attention. The research in "Studies conducted on students" engagement" and "factors influence students" engagement" are also high. Generally, the figure shows that research in students' engagement is rapidly increasing.

Fig. 5 shows the taxonomy of literature on students' engagement. The first category is the "overview", in which two topics are discussed under this category, definitions, and history. The results show that the literature on students' engagement can be traced back to at least 70 years ago and it received more attention from researchers since the mid-1980s. The second category is the dimensions and indications. Four dimensions have been identified which are behavioral engagement, emotional engagement, cognitive engagement, and social engagement, each of which has a number of indications. The results show that emotional engagement received less attention while social engagement is just recently discussed in the literature and it requires more research.

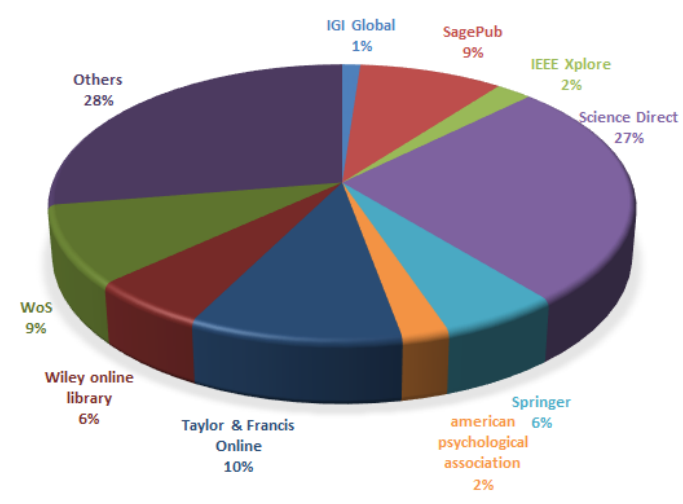

Fig. 3. Identity of the Source Databases of the Reviewed Articles.

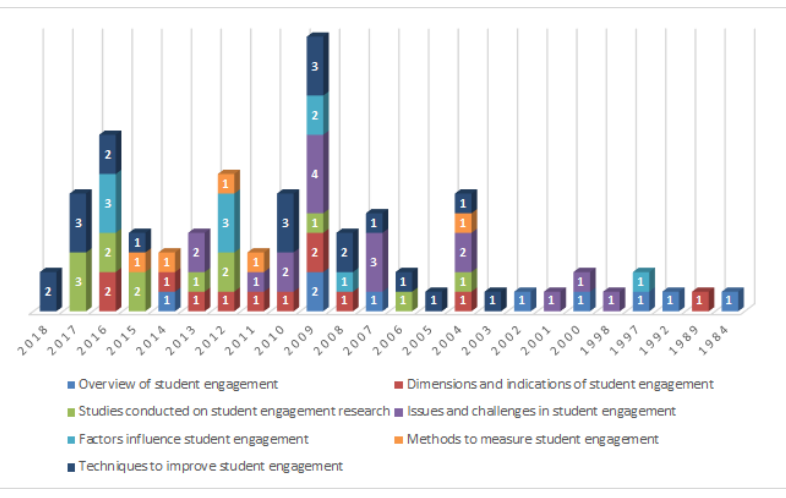

Fig. 4. Number of Articles in different Categories by Year of Publication. 


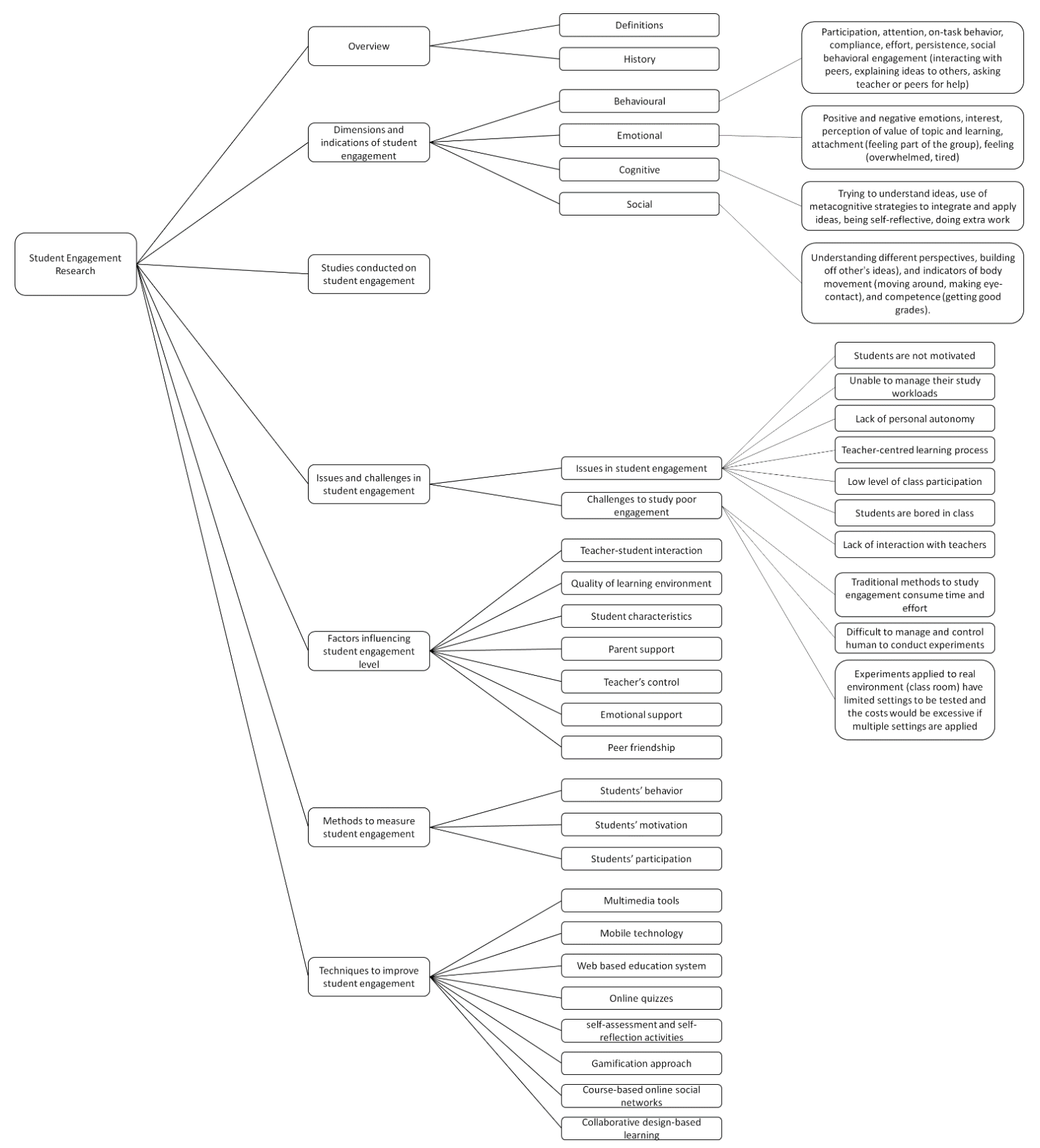

Fig. 5. Taxonomy of Literature on Students' Engagement.

The third category is "studies conducted on students" engagement". The results show that there are a number of studies that have been made either on the subject domain such as mathematics and science subjects or on the level domain such as primary or secondary school students. The results also show that there is a broad agreement in the literature that students' engagement is a multi-dimensional construct in either subject domain or level domain; the most prevalent dimensions are behavioral, emotional/ affective, and cognitive engagement. The fourth category is "Problems in students' engagement", the issues and challenges of which have been presented [26]. The results show that the issue of poor engagement often arises within middle school and aggravates during high school and becomes worse at the university level. Several issues have been revealed such as students are not motivated; unable to manage their study workloads; lack of personal autonomy; teacher-centered learning process; lowlevel class participation; bored in class; and lack of interactions with teachers.

The review also reveals that one of the main challenges to study these issues is the limitation of traditional research tools. Studies indicate that traditional methods consume time and effort, difficult to manage and control human subjects to conduct experiments; and experiments applied to real environment (classroom) have limited settings to be tested and the costs would be excessive if multiple settings are applied. 
Under the fifth category "Factors influencing student engagement level", seven factors have been identified. The results show that teachers have a significant role among the relative factors postulated to influence students' engagement such as parents, friends, students' characteristics and learning environment. A teacher's role could be classified into a teacher's control, teacher's support, and teacher-students' interactions. The sixth category is "Methods to measure student engagement", the results of which show that there are three indicators that could be utilized to measure or evaluate students' engagement which are participation level, motivation level, and their positive or negative behaviour.

The last category is "Techniques to improve students' engagement". Several technologies have been deployed to enhance engagement and subsequently, educational outcomes. The results show positive attempts by researchers to engage students using multimedia tools, mobile technology, and webbased systems. However, these techniques might not be applicable in real situations due to the absence of one or more implementation requirements such as limitation of time, resources, teacher capability, and suitable environment.

\section{STUDENT ENGAGEMENT RESEARCH}

Students who are engaged receive more teacher involvement, highly motivated to attend classes, and actively involved in classroom discussions [7]. Disengaged students are more likely to find that teachers become more controlling and increasingly withdraw their support, thereafter develop habitual truant and/or occasionally misbehave in classrooms [7].

\section{A. Overview of Student Engagement}

Kuh [8] define student engagement as "participation in educationally effective practices that lead to a range of measurable outcomes". Student engagement promotes both emotional wellbeing and learning outcomes. Research has highlighted the negative effect boredom can have on emotional wellbeing on students [9]. In Student Engagement Literature Review by Trowler [10], he states this research gained widespread attention particularly in North America and Australasia where the large scale of student engagement survey took place. Most prolific researchers such as Kuh [11] and Coates [12] developed and implemented large scale of national student engagement surveys within several universities.

According to Kuh [8], a theory of students' engagement has been deliberated in the literature for more than 70 years and attracted widespread attention of social researchers in the literature since the mid-1980s [10] [13]. Harper [14] postulated engagement "is more important than involvement or participation as it requires feelings and sense-making as well as activity". The past twenty years of research on students' engagement indicate that engagement and motivation lead to higher achievements of the students' performance [15]. In a nutshell, for a good purpose, a huge number of researchers have studied and investigated students' engagement due to deteriorating engagement over the years [16].

\section{B. Dimensions and Indications of Student Engagement}

Initially, Finn [17] introduced two-component student engagement models; Participation and Identification (PI) Model. In his terms, Participation refers to "behavioral engagement" and Identification refers to "affective/emotional engagement". Since many researchers have shown interest to pursue engagement research, the multi-dimensional model becomes more popular. Therefore, Fredricks et al. [18] suggest that three different components that construct students' engagement which are behavioral, emotional, and cognitive as shown in Fig. 6. Educational institutions has highly recognized the significance of students' engagement as it is widely noticed that many students are suffering from several disengagement indicators such as bored, unmotivated, and uninvolved from the academic and social aspects of school life [19].

The Behavioral component is reflected by student compliance with school rules such as attendance. The Emotional component concerns student's feeling that reflected by attitude, belongingness and his/her opinion towards the school. Finally, Cognitive component is reflected by learning involvement.

Recently, another engagement component has been proposed by literature named social that is reflected by social interaction in learning process [20] [21] [22].

This classification of student's engagement (behavioral, emotional, cognitive, and social) is supported by other research works such as in [23] [24] [25] they confirmed these types via interview session, it is also observed that these types have long-term impact on better academic results [27].

\section{Studies Conducted on Students' Engagement Research}

Previous studies have shown that levels of engagement are directly related to academic achievement in some particular subjects [17] [18] [28]. Therefore, there are few studies that aim to investigate subject-specific students' engagement in Mathematics, Science, Malaysian Studies and English Language. A study conducted by Martin et al. [29] reports that engagement in mathematics and science subjects deteriorate during the secondary school years. Hence, Wang et al. [30] develop and validate student and teacher-report survey to measure students' engagement in mathematics and science by proposing a bifactor modeling approach.

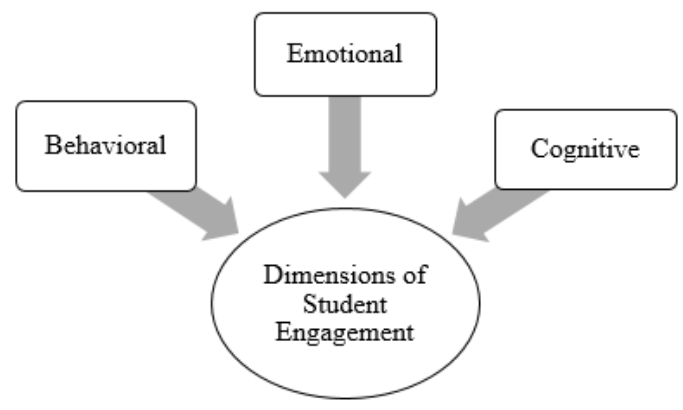

Fig. 6. Dimensions of Student Engagement. 
In another study, Ayub et al. [31] investigate mathematics engagement by focusing on the cognitive, affective and behavioral engagement domains among secondary school students. A total number of 387 students from urban and rural secondary schools in Pahang, Malaysia, were randomly selected. According to PISA survey conducted in 2012, engagement performance in mathematics lesson declined among Malaysian students. Thus, in their research, they suggest that teachers should restructure their teaching strategy by creatively devising new techniques in teaching mathematics. Consequently, when planning for mathematics activities or strategies, crucial elements of engagement; cognitive, behavioral and emotional are accounted for to improve engagement in mathematics lessons. The researchers also emphasize strategies that are needed to be integrated during the teaching should not be too teacher-centered [31].

In a similar study conducted at a public university, Universiti Putra Malaysia, the researchers investigate the relationship between students' attitudes toward statistics and mathematics engagement among 293 undergraduate students who are enrolled in statistics courses from several programs [32]. Their analysis of mathematics and statistics engagement domain reveals that attitudes towards statistics are positively related to the emotional domain, then a cognitive domain and followed by a behavioural domain. Their findings show attitudes are vital for students to be engaged in mathematics and statistics [32].

In the Malaysian context, lecturers face challenges in teaching theoretical subjects like Malaysian Studies and English Language because students complain that these subjects are irrelevant and not engaging [32]. Through their study, it is found that project-based learning is an approach to improve students' engagement [33] [34]. However, a lack of commitment from students and time-consuming are the barriers to implement project-based learning. They suggest that the lecturers can alleviate the difficulties in practicing project-based learning if they are well-equipped with the knowledge and skills in executing this strategy. In another study by Willms et al. [35], two social studies teachers and 24 secondary school students are involved. From their analysis, they found that students display engagement as they engage behaviorally and emotionally and enjoy their assessment in a group.

Ishak and Amjah [36] discovered that the level of engagement is fair for the first activity as expressed by their participation and interest, and enthusiastic to work in group. The study dedicated for teachers to realize the importance of engagement in learning. Teoh et al. [37] conducted a quationnaire for a total of 64 students and they identified five indices of students' engagement "student-faculty interaction", "cooperation among students", "life-long learning", "and experience with diversity", "active learning". Further investigation reports other aspects such as imaginative teaching practice, prompt feedback to students' work, react fairly to students' performance and suitable teaching strategy would encourage involvement and commitment of students in their studies.
Even though there is a broad agreement in the literature that students' engagement is a multi-dimensional construct and some notable research use variations ranging from two to four dimension; behavioral, cognitive, emotional and social. Despite these inconsistencies, the most prevalent dimension in the literature is that engagement consists of three distinct dimensions; behavioral, emotional/affective and cognitive engagement [18]. Among these, behavioral engagement receives the most attention and emotional engagement, the least [18]. From our analysis, a few prominent researches use this crucial multi-dimensional focus in subject domains or among primary/secondary school students. However, past investigations report that tertiary level institutions face more signs of poor engagement or lack of commitment to studies [38]. Furthermore, Krauss et al., [39] report that existing studies on school engagement have been mostly limited to individual and school-based predictors in Western countries.

\section{Problems in Students' Engagement}

Issues of poor engagement often arise within middle school and are aggravated during high school [39]. Marks [19] and Stipek and Byler [40] report that there is a steady decline from the middle to high school students in affective interest and motivation to learn, followed by a decline in cognitive enthusiasm to face challenges in tasks. Furthermore, evidence supported by Willms et al. [41] shows that poor engagement usually becomes a concern in middle school and high school.

It was discovered by several studies conducted in Australia and the United States the performance in of undergraduates is declining as students are motivated to study and they are less involved with university activities [42]. Besides, according to Astin \& Sax [43], students less requesting teacher's advice, oversleeping and absence from classes.

Another study by Thang [44] and Ming and Alias [45] conducted on public and private universities of Malaysia, the result showed that majority of students experience a teachercentered learning process and lack personal autonomy.

In general, Asian students are suffering from low-level class of engagement and more that $80 \%$ of students do not ask questions during class this is due to their disinterest with the lessons [46] [47] [48]. Another study by UCLA discovered that $40 \%$ of students are not engaged and feel boring during class and 59\% are get bored at least half of their classes [49] [50]. Another survey by Indiana University revealed that due to the lack of interaction with teachers, $30 \%$ of the students are engaged and $75 \%$ of the students are not interested with the given subjects [51] [52]. On the other hand, Researchers have used traditional methods such as survey and questionnaire to study and investigate students' engagement consume a lot of time and efforts and limited settings as repeating an experiment with different settings, gathering a huge crowd of students would be tedious [53] [54] [55].

\section{E. Factors Influencing Students' Engagement Level}

Apparently, high-level engagements in classrooms are related to enhanced achievement, attained knowledge, skill and effective learning [56]. Better engagement produces better emotional functioning [57]. The purpose of engagement in the classroom is to serve as a protector against student drop out 
issues and to prevent students' involvement in unhealthy activities [57]. Research findings indicate that students' engagement is correlated to academic performance, and their disengagement leads to poor academic performance in a variety of subjects or domains [12].

Recent results reveal that parent support for basic psychological needs seems to be the most significant factor in either academic motivation or dropping out cases [58]. In addition, parental monitoring and family cohesion are reported as predictors of engagement [39]. Further findings indicate that supportive relationships with lecturers are significantly associated with students' engagement [39]. According to Abdullah et al. [59], students' personality, environment, and influence of instructors and peers are factors that are able to motivate students' engagement throughout the lesson. Ricard and Pelletier [58] also agree that peer friendship affects motivation, persistence, and engagement in a classroom.

In another research, Shernoff et al. [60] use the Experience Sampling Method (ESM) to predict students' engagement and experience. Their demonstration shows that the quality of the learning environment contributes to students' engagement and a sense of classroom self-esteem. Even though students' characteristics substantively influence their motivation, learning, and quality of learning environment directly or indirectly influence the students' academic performance [61]. It is also believed that students' engagement in the classroom is influenced by teachers' control [61]. Teachers' role is essential for the quality of learning process and students' experiences [62]. In addition, teachers' support and caring have been found to be pivotal in students' engagement. Carroll et al. [63], state that the teacher is the strongest factor after students' characteristics. The teacher influences the students via a variety of activities such as assisting students, providing instructional, emotional and organizational support. Based on the findings by Lam et al. [64], among the relative factors postulated to influence students' engagement, teacher-student interaction has received significant endorsement. Fig. 7 depicts the factors that influence students' engagement.

\section{F. Methods to Measure Students' Engagement}

Another approach to defining student engagement is to see how it is measured. For centuries, few common measures have been practiced to identify if students are actively engaged or involved in the learning process. These measures mainly focused on the traditionally "quantifiable" aspects of student behavior, attendance rates, truancy, time-on-task, and consequently suspension/discipline rates [65]. Generally, highly motivated student always attends the classes and score standardized test. However, demotivated students always absence to class and possess poor academic performance. Researchers stressed that more systematic approach to the measurement of engagement is the most imperative for future research direction [4] [66].

Other indicators that have been used to measure engagement in the literature include teacher ratings, interviews, observations, cross-cultural data and assessments grades [6] [4] [5]. On the other hand, extra guidance and culture of explanation instead of the culture of right answer are other ways to measure students' engagement. Similarly, as reported by Fredricks \& McColskey [4], students are encouraged to participate in a classroom by honestly selfreflecting their understanding of the lesson before moving onto the next lesson. For example, each student can rate their understanding from 1-3 (1 is lowest understanding rate and 3 is highest understanding rate). By rating their understanding, they can reflect what was taught.

An impressive way to measure students' engagement is to ask questions in a classroom. Typically, when a question is asked, the same person will raise each time. This issue might lead to inattention in the classroom. Thus, overall students' participation is required to measure the students' engagement [10].

\section{G. Computational Methods/Techniques to Improve Students' Engagement}

When teachers lack the resources, ideas, and materials to effectively manage the social and emotional challenges within the particular context of a classroom, students show poor interest in on-task behavior and performance [67]. Therefore, many researchers proposed methods or techniques to engage students with lessons despite the factors influencing it. Table 1 shows examples of techniques in the literature.

Windham [68] recommends the concept of "interaction, exploration, relevancy, multimedia and instruction" for students' engagement activities that strengthen the interaction of lecturers with their students and at the same time monitor how their students learn. Students are given the opportunity to interact with someone successful in their field as opposed to being theoretical and text-based. Applying real-life scenarios focused on keeping young students engaged and motivated. Engagement is a major condition for learning, in fact, outdated educational systems fail to sustain the interest and objectives of millennials generation which is infused with digital technologies [68]. Innovative and fun context of teaching strategy is essential to promote engagement. A variety of multimedia tools and incorporating technology into learning activities have been shown to increase students' interest, higher achievement, improved quality of work, higher students' motivation, and improved information literacy and critical thinking skills [70]. For example, using mobile devices for research and social-based learning activities have been shown to upsurge their engagement by as much as $78 \%$ [71].

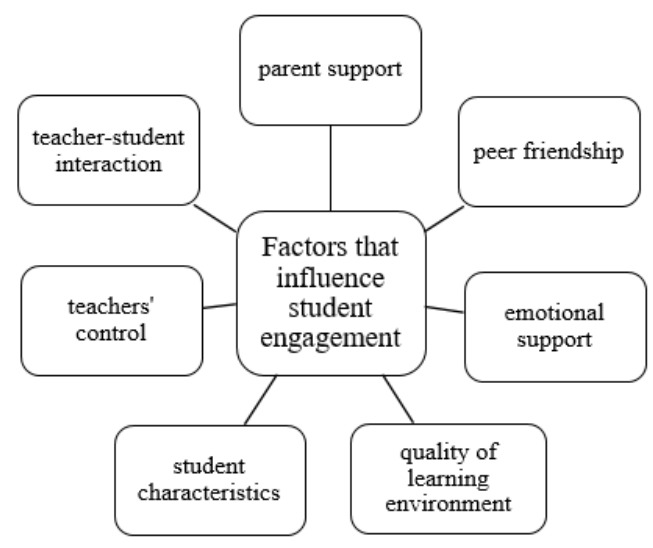

Fig. 7. Factors that Influence Student Engagement. 
TABLE. I. Computational Methods / TeChniques to ENGage Students

\begin{tabular}{|c|c|}
\hline Reference & Techniques \\
\hline Krause \& Coates [82] & 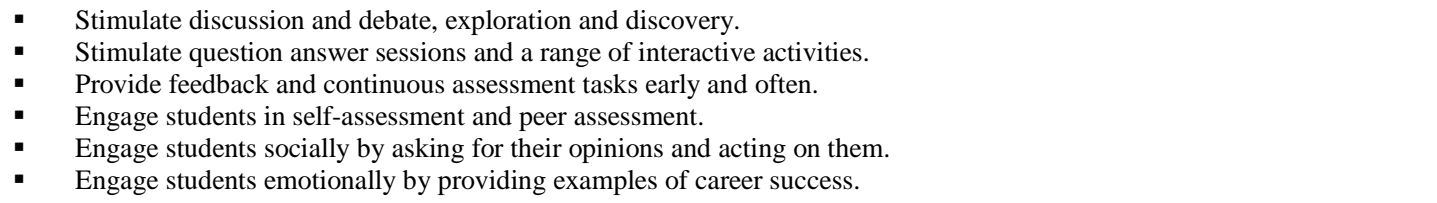 \\
\hline Tizzard [83] & $\begin{array}{l}\text { Use of free software such as Xtranormal to create videos as learning objects, weekly reminders, and FAQ videos. } \\
\text { Interactive chat room experience. } \\
\text { On-line quizzes as self-assessment tools. }\end{array}$ \\
\hline Parsons \& Taylor [65] & $\begin{array}{l}\text { - Use technology in the classroom. } \\
\text { - Reduce lectures, increase group-discussion time, and ignore the "multitasking" student. }\end{array}$ \\
\hline Windham 68] & $\begin{array}{l}\text { Interaction - Connect with experts and expertise } \\
\text { Exploration - hands-on, inquiry-based, problem-based, and exploratory, new forms of digital media (video games, social } \\
\text { media, and websites) } \\
\text { Relevancy - Apply real-life scenarios } \\
\text { Multimedia - multimedia tool (e.g. WebQuests, blogs, wikis, YouTube, video documentaries), iPhones and other mobile } \\
\text { devices for research. } \\
\text { Cameras, video, and video editing, projectors, sound recording equipment, animation and gaming software, and the } \\
\text { ubiquitous PowerPoint } \\
\text { Instruction - formative assessment }\end{array}$ \\
\hline Frondeville [84] & $\begin{array}{l}\text { - Use Quickwrites - short journal-writing assignment, summarize and predict an exam or quiz question. } \\
\text { Use signaling to allow everyone to answer a question - asking questions that allow for multiple answers or explanations } \\
\text { Introduce a presentation by having students pair up, talk to each other about their prior knowledge of the presentation, and } \\
\text { generate a list of four questions. }\end{array}$ \\
\hline Maheady \& Gard [85] & $\begin{array}{l}\text { - ClassWide Peer Tutoring (CWPT) is a low-cost, efficient instructional intervention that enhances student achievement by } \\
\text { increasing opportunities for active responding and immediate feedback. }\end{array}$ \\
\hline Rathvon [86] & - $\quad$ Response card instruction - students respond to teacher questions by writing on cards \\
\hline Falcão et al. [69] & - $\quad$ Fun and interactive context of strategy \\
\hline Heflin et al. [72] & $\begin{array}{l}\text { Use of mobile technologies for learning } \\
\text { Promote collaborative learning }\end{array}$ \\
\hline Goyal \& Krishnamurthy [74] & $\begin{array}{l}\text { - Use of web-based system, for example, online learning material } \\
\text { Better organize content } \\
\text { Cater different type of students }\end{array}$ \\
\hline Russell et al. [75] & $\begin{array}{l}\text { Online quizzes } \\
\text { Relevant to real-world applications }\end{array}$ \\
\hline Wang [76] & $\begin{array}{l}\text { - Self-assessment and self-reflection activities } \\
\text { Problem-solving activities }\end{array}$ \\
\hline Dim et al. [77] & - Gamification approach for example gamified online discussion tool \\
\hline Imlawi et al. [78] & - Create online course-based social networks to interconnect with their students \\
\hline Chen and Chiu [80] & $\begin{array}{l}\text { - Intergroup competition mechanism and integrate it into a multi-touch platform for collaborative design-based learning } \\
\text { (DBL). }\end{array}$ \\
\hline
\end{tabular}

Heflin et al. [72] investigate the impact of mobile technology on students' attitudes, engagement, and learning. Their findings indicate that mobile technology is allied with positive students' perceptions of collaborative learning. This clearly shows that multimedia and technology have been proven to be helpful in engaging students, exploring ways to present their ideas [71] [73].

Recently, web-based education systems have been a popular topic. Goyal and Krishnamurthy [74] suggest that cognitive strategies have a vital role to design web-based systems. Students utilize strategies when learning any subject from online learning materials. The purpose of a web-based education system is to better organize the content that caters to different characteristics of students in the learning process.

In a study by Wang [76], she identifies that a course design improves students' behavior, emotional and cognitive engagements that promote high achievement in their studies. In addition, her findings indicate that engagement in selfassessment and self-reflection activities have an important impact on online studies and social interaction, which produce a significant engagement in problem-solving activities [76]. 
Ding et al. [77] emphasize on gamification approach to foster students' engagement. They developed a gamified online discussion tool, gEchoLu to examine students' engagement in online discussions. Their results indicate that gEchoLu has positive effects on student behavioral, emotional, and cognitive engagement [77].

In another study, Imlawi et al. [78] analyze the impact of students' engagement in course-based social networks and observe educational outcomes. Their findings recommend that teachers who create online course-based social networks to interconnect with their students are able to improve their engagement, motivation, and satisfaction. In addition, they provide strategies for teachers to fit their activities and enhance their students' engagement and educational outcomes.

In addition, Up [79] indicates that technology improves students' engagement including cognitive, affective, behavioral, academic, and social engagement. Therefore, lecturers need to find techniques to motivate their students to learn and increase participation rates so that their time is devoted to learning and there is no room for misbehavior. Despite the advantages of digital technology in promoting students' engagement, Chen and Chiu [80] propose and develop an intergroup competition mechanism and integrate it into a multi-touch platform for collaborative design-based learning (DBL). Their analyses show that students who participate in intergroup competition significantly foster better students' engagement, learning achievement, and creativity [81].

\section{DISCUSSION AND RECOMMENDATIONS}

From our study and analysis of the literature, we have identified several issues worth investigating.

\section{A. Examining the Impact of Emotion on Students' \\ Engagement}

Despite the vast amount of research in students' engagement areas, students' emotional engagement still lacks conceptual clarity due to little attention from social studies' researchers [9] [57]. Studies on emotions have not been deeply investigated by researchers as a major factor in shaping students' engagement [9]. A few studies have examined academic emotions as a predictor for dropout, in addition to their influence on achievement [57] [87] [88]. It is recommended that investigation should be made to enhance emotional engagement in a classroom by examining a lecturer emotional states [89].

\section{B. Development of a Configuration Framework to Generate an Engagement-Strategy for a Particular Classroom Environment}

As discussed in Section 4, there are a number of interesting techniques and strategies that have been proposed by researchers. However, we do not expect that teachers will review all these techniques and strategies to identify the suitable and applicable to their classroom environment. Therefore, we suggest here to develop a configuration framework that is able to generate a suitable strategy from some given inputs by a teacher such as a classroom environment, subject nature, available resources, teacher's capability and so forth. To exploit all the proposed techniques and strategies efficiently, they should be compiled in a system and by using the configuration framework, the system can offer some recommendations.

\section{Utilizing the Concept of Computer-based Simulation and Virtual Environment to Study and Investigate Poor Students' Engagement Instead of using Traditional Research Tools}

Modeling and simulation gain more attention [90] [91] [92] [93], the demand on reducing time and resource costs associated with development and validation of simulation models have also increased [94] [95] [96]. Simulation is useful when the phenomenon to be studied is not directly accessible or is difficult to observe directly ([97] [98] [99]. The idea of experimenting with models rather on the real system is not something new [100] [101] [102].

One of the potential methods that could be utilized is an agent-based social simulation (ABSS) [102] [103]. ABSS is a method to model systems that comprise of individual, autonomous, cooperating agents [53] [104]. This method can be used to model human behaviors and their effects on others [105]. Social scientists have begun to convert social theories to computer programs [106]. It is then possible to simulate social processes and carry out "experiments" that would otherwise be impossible [107] [108] [109].

\section{CONCLUSION, LIMITATION AND FUTURE WORKS}

In this paper, existing research in various categories of students' engagement is thoroughly reviewed. A collection of selected papers is classified into seven categories, overview; dimensions and indications; research studies; problems; factors influence engagement; methods to measure engagement; and techniques to improve engagement. We first describe the method to conduct this review, which includes search strategy, search terms, and selection process.

We then review the papers in each category, present the definitions and history of students' engagement under the overview category. Under the dimensions and indications category, we present the behavioural; emotional; cognitive and social dimensions and their indications. We then review 13 research studies on students' engagement, identifying issues and challenges including disengaged issues in middle school, high school, and university levels. We found that the main challenge of studying the disengagement problem is that the traditional research tools lack flexibility and the technique is tedious and costly. Subsequently, we conduct a comprehensive analysis that includes data analysis on students' engagement studies, number of selected articles by year of publication, rate of reviewed articles in different categories, number of articles in different categories by year of publication, and finally taxonomy of literature on students' engagement. This is followed by a discussion and recommendations section. In which three potential research problems are discussed. The problems are examining the impact of emotion on students' engagement; development of a configuration framework to generate an engagement-strategy for a particular classroom environment; utilizing the concept 
of computer-based simulation and virtual environment to study and investigate poor engagement instead of using traditional research tools. The main limitation of this review is the number of reviewed papers in some categories, albeit the papers are reliable and are broadly representative collections. Another limitation is the rapid progress and development in this field has potential to limit the timeliness of the survey.

In our future work, we shall study and analyze the importance and challenges of emotions to students' engagement to highlight factors influencing lecturers' emotions and students' emotional states that affect students' engagement in a classroom. In addition, instead of using traditional methods in studying students' engagement such as a questionnaire survey, we shall develop a simulation program that could potentially help researchers in the field of social studies to apply various environmental settings and study the impact of different strategies.

\section{REFERENCES}

[1] Chapman, C., Laird, J., Ifill, N., \& KewalRamani, A. (2011). Trends in High School Dropout and Completion Rates in the United States: 19722009. Compendium Report. NCES 2012-006. National Center for Education Statistics.

[2] Fredricks, J. A., Filsecker, M., \& Lawson, M. A. (2016). Student engagement, context, and adjustment: Addressing definitional, measurement, and methodological issues, Learning and Instruction, volume 23, pp 1-4.

[3] Salleh, A. M., Desa, M. M., \& Tuit, R. M. (2013). The Relationship between the Learning Ecology System and Students' Engagement: A Case Study in Selangor. Asian Social Science, 9(12), 110.

[4] Fredricks, J. A., \& McColskey, W. (2012). The measurement of student engagement: A comparative analysis of various methods and student self-report instruments. In Handbook of research on student engagement (pp. 763-782). Springer US.

[5] Castro, S., Granlund, M., \& Almqvist, L. (2015). The relationship between classroom quality-related variables and engagement levels in Swedish preschool classrooms: a longitudinal study. European Early Childhood Education Research Journal, 1-14.

[6] Reeve, J., Jang, H., Carrell, D., Jeon, S., \& Barch, J. (2004). Enhancing students' engagement by increasing teachers' autonomy support. Motivation and emotion, 28(2), 147-169.

[7] Skinner, E. A., \& Belmont, M. J. (1993). Motivation in the classroom: Reciprocal effects of teacher behaviour and student engagement across the school year. Journal of educational psychology, 85(4), 571.

[8] Kuh, G. D., (2009). 'Afterword', in Harper, S. R., \& Quaye, S. J., (Eds.), Student Engagement in Higher Education (New York and London, Routledge) pp. 313-18.

[9] Pekrun, R., Cusack, A., Murayama, K., Elliot, A. J., \& Thomas, K. (2014). The power of anticipated feedback: Effects on students' achievement goals and achievement emotions. Learning and Instruction, $29,115-124$.

[10] Trowler, V. (2010). Student engagement literature review. The Higher Education Academy, 11, 1-15.

[11] Kuh, George D. "What student affairs professionals need to know about student engagement." Journal of College Student Development 50, no. 6 (2009b): 683-706.

[12] Coates, H. (2007). A model of online and general campus- based student engagement. Assessment \& Evaluation in Higher Education, 32(2), 121-141.

[13] Astin, A. W. (1984). Student involvement: A developmental theory for higher education. Journal of college student personnel, 25(4), 297-308.

[14] Harper, S. R. (2009). Institutional seriousness concerning Black male student engagement: Necessary conditions and collaborative partnerships. Student engagement in higher education: Theoretical perspectives and practical approaches for diverse populations, 137-156.
[15] Brewster, C., \& Fager, J. (2000). Increasing student engagement and motivation: From time-on-task to homework. Portland, OR: Northwest Regional Educational Laboratory.

[16] Schlechty, P. C. (2002). Working on the Work: An Action Plan for Teachers, Principals, and Superintendents. The Jossey-Bass Education Series. Jossey-Bass, 989 Market Street, San Francisco, CA 94103-1741.

[17] Finn, J. D. (1989). Withdrawing from school. Review of educational research, 59(2), 117-142.

[18] Fredricks, J .A ., Blumenfeld, P .C . and Paris, A .H . (2004) School Engagement: Potential of the Concept, State of the Evidence . Review of Educational Research . 74 (1), pp .59-109.

[19] Marks, H. M. (2000). Student engagement in instructional activity: Patterns in the elementary, middle, and high school years. American educational research journal, 37(1), 153-184.

[20] Fredricks, J. A., Wang, M. T., Linn, J. S., Hofkens, T. L., Sung, H., Parr, A., \& Allerton, J. (2016). Using qualitative methods to develop a survey measure of math and science engagement. Learning and Instruction, 43, $5-15$.

[21] Linnenbrink-Garcia, L., Rogat, T., \& Koskey, K. (2011). Affect and engagement durings mall group instruction. Contemporary Educational Psychology, 36, 13-24

[22] Finn, J. D., \& Zimmer, K. (2012). Student engagement: what is it and why does it matter? In S. Christenson, A. L. Reschy, \& C. Wylie (Eds.), Handbook of research on student engagement (pp. 97e131). New York: Springer.

[23] Boekaerts, M. (2016). Engagement as an inherent aspect of the learning process. Learning and Instruction, 43, 76-83.

[24] Luo, W., Hughes, J. N., Liew, J., \& Kwok, O. (2009). Classifying academically at-risk first graders into engagement types: Association with long-term achievement trajectories. The Elementary school journal, 109(4), 380-405.

[25] Eccles, J. (2009). Who am I and what am I going to do with my life? Personal and collective identities as motivators of action. Educational Psychologist, 44(2), 78-89.

[26] Appleton, J. J., Christenson, S. L., \& Furlong, M. J. (2008). Student engagement with school: Critical conceptual and methodological issues of the construct. Psychology in the Schools, 45(5), 369-386.

[27] Kahu, E. (2014). Increasing the emotional engagement of first year mature-aged distance students: Interest and belonging. The International Journal of the First Year in Higher Education, 5(2), 45.

[28] Akey, T. M. (2006). School Context, Student Attitudes and Behaviour, and Academic Achievement: An Exploratory Analysis. MDRC.

[29] Martin, J. Way, J. Bobis, J. Anderson. (2015). Exploring the ups and downs of math engagement in the middle school years, Journal of Early Adolescence, 35,pp. 199-244.

[30] Wang, M. T., Fredricks, J. A., Ye, F., Hofkens, T. L., \& Linn, J. S. (2016). The Math and Science Engagement Scales: Scale development, validation, and psychometric properties. Learning and Instruction, 43, 16-26.

[31] Ayub, A. F. M., Yunus, A. S. M., Mahmud, R., Salim, N. R., \& Sulaiman, T. (2017, January). Differences in students' mathematics engagement between gender and between rural and urban schools. In A. Kilicman, H. M. Srivastava, M. Mursaleen, \& C. M. Khalique (Eds.), AIP Conference Proceedings (Vol. 1795, No. 1, p. 020025). AIP Publishing.

[32] Salim, N. R., \& Ayub, A. F. M. (2017, January). Relationship between mathematics statistics engagement and attitudes towards statistics among undergraduate students in Malaysia. In A. Kilicman, H. M. Srivastava, M. Mursaleen, \& C. M. Khalique (Eds.), AIP Conference Proceedings (Vol. 1795, No. 1, p. 020026). AIP Publishing.

[33] Aiedah, A. K., \& Audrey, L. K. C. (2012). Application of project-based learning in students' engagement in Malaysian Studies and English Language. Journal of Interdisciplinary Research in Education (JIRE), 2(1), 37-46.

[34] Learning Point Associates (2004a). Engaged in the Learning Process, Illinois: North Central Regional Educational Laboratory (NCREL). Retrieved October 3, 2016 from http:/ /www.ncrel.org/sdrs/areas/issues/ content/cntareas/science/sc4engag.htm. 
[35] Willms, J. D., Friesen, S., \& Milton, P. (2009). What did you do in school today? Transforming classrooms through social, academic and intellectual engagement. (First National Report) Toronto: Canadian Education Association.

[36] Ishak, Z., \& Amjah, D. Y. P. H. (2015). An Exploratory Study on Students' Engagement in Social Studies of Year 7. Journal of Management Research, 7(2), 433.

[37] Teoh, H. C., Abdullah, M. C., Roslan, S., \& Daud, S. (2013). An investigation of students' engagement in a Malaysian Public University. Procedia-Social and Behavioural Sciences, 90, 142-151.

[38] Kazmi, A. (2010). Sleepwalking through Undergrad: Using Student Engagement as an Institutional Alarm Clock. College Quarterly, 13(1), $\mathrm{n} 1$.

[39] Krauss, S. E., Kornbluh, M., \& Zeldin, S. (2017). Community predictors of school engagement: The role of families and youth-adult partnership in Malaysia. Children and Youth Services Review.

[40] Stipek, D., \& Byler, P. (2004). The early childhood classroom observation measure. Early Childhood Research Quarterly, 19(3), 375397.

[41] Willms, J. D., Friesen, S., \& Milton, P. (2009). What did you do in school today? Transforming classrooms through social, academic and intellectual engagement. (First National Report) Toronto: Canadian Education Association.

[42] McInnis, C. (2001). Signs of Disengagement? The Changing Undergraduate Experience in Australian Universities. Inaugural Professorial Lecture.

[43] Astin, A. W., \& Sax, L. J. (1998). How undergraduates are affected by service participation. Service Participation, 39(3), 251.

[44] Thang, S. M. (2009). Investigating autonomy of Malaysian ESL learners: A comparison between public and private universities. 3L; Language, Linguistics and Literature, The Southeast Asian Journal of English Language Studies., 15, 97-124.

[45] Ming, T. S., \& Alias, A. (2007). Investigating readiness for autonomy: A comparison of Malaysian ESL undergraduates of three public universities. Journal of Reflections on English Language Teaching, 6(1), $1-18$.

[46] Dasari, B. (2009). Hong Kong students' approaches to learning: crosscultural comparisons. US-China Education Review, 6(12), 46-58.

[47] Sayadi, Z. A. (2007). An investigation into first year engineering students' oral classroom participation: a case study. Universiti Teknologi Malaysia, Faculty of Education.

[48] Mustapha, S. M., \& Rahman, N. S. N. A. (2011). Classroom participation patterns: A case study of Malaysian undergraduate students. EDUCARE, 3(2).

[49] Pryor, J. H., Hurtado, S., DeAngelo, L. E., Blake, L. P., \& Tran, S. (2010). The American freshman: National norms fall 2009. Univ of California Press.

[50] Mann, S., \& Robinson, A. (2009). Boredom in the lecture theatre: An investigation into the contributors, moderators, and outcomes of boredom among university students. British Educational Research Journal, 35(2), 243-258.

[51] Yazzie-Mintz, E. (2010). Charting the path from engagement to achievement: A report on the 2009 High School Survey of Students' engagement . Bloomington, IN: Center for Evaluation \& Education Policy.

[52] Nikish. C, (2013) Hobsons (http://www.hobsons.com)Students' Engagement (Http://Www.Naviance.Com/Blog/C/Stude Ntengagement).

[53] Macal, C. M., \& North, M. J. (2009, December). Agent-based modeling and simulation. In Winter simulation conference (pp. 86-98). Winter Simulation Conference.

[54] Bousquet, F., \& Le Page, C. (2004). Multi-agent simulations and ecosystem management: a review. Ecological modelling, 176(3), 313332.

[55] Lawson, J., \& Silver, H. (2013). A social history of education in England. Routledge.

[56] Barkatsas, A. T., Kasimatis, K., \& Gialamas, V. (2009). Learning secondary mathematics with technology: Exploring the complex interrelationship between students' attitudes, engagement, gender and achievement. Computers \& Education, 52(3), 562-570.

[57] Skinner, E., Furrer, C., Marchand, G., \& Kindermann, T. (2008). Engagement and disaffection in the classroom: Part of a larger motivational dynamic?. Journal of Educational Psychology, 100(4), 765.

[58] Ricard, N. C., \& Pelletier, L. G. (2016). Dropping out of high school: The role of parent and teacher self-determination support, reciprocal friendships and academic motivation. Contemporary Educational Psychology.

[59] Abdullah, M. Y., Bakar, N. R. A., \& Mahbob, M. H. (2012). Student's Participation in Classroom: What Motivates them to Speak Up? Procedia-Social and Behavioural Sciences, 51, 516-522.

[60] Shernoff, D. J., Kelly, S., Tonks, S. M., Anderson, B., Cavanagh, R. F., Sinha, S., \& Abdi, B. (2016). Student engagement as a function of environmental complexity in high school classrooms. Learning and Instruction.

[61] Wubbels, T., Brekelmans, M., Mainhard, T., den Brok, P., \& van Tartwijk, J. (2016). Teacher-Student Relationships and Student Achievement. Handbook of Social Influences in School Contexts: Social-Emotional, Motivation, and Cognitive Outcomes, 127.

[62] Christenson, S. L., Reschly, A. L., \& Wylie, C. (2012). Handbook of research on student engagement. New York, NY: Springer].

[63] Carroll, A., Houghton, S., Wood, R., Unsworth, K., Hattie, J., Gordon, L., \& Bower, J. (2009). Self-efficacy and academic achievement in Australian high school students: The mediating effects of academic aspirations and delinquency. Journal of Adolescence, 32(4), 797-817.

[64] Lam, S. F., Jimerson, S., Kikas, E., Cefai, C., Veiga, F. H., Nelson, B., $\&$ Farrell, P. (2012). Do girls and boys perceive themselves as equally engaged in school? The results of an international study from 12 countries. Journal of school psychology, 50(1), 77-94.

[65] Parsons, J., \& Taylor, L. (2011). Improving student engagement. Current issues in education, 14(1).

[66] Veiga, F., Reeve, J., Wentzel, K., \& Robu, V. (2014). Assessing students' engagement: A review of instruments with psychometric qualities. In I Congresso Internacional Envolvimento dos Alunos na Escola: Perspetivas da Psicologia e Educação (pp. 38-57).

[67] Marzano, R. J., Marzano, J. S., \& Pickering, D. (2003). Classroom management that works: Research-based strategies for every teacher. ASCD.

[68] Windham, c. (2005). The student's Perspective. In D. Oblinger\& J.Oblinger (Eds), educating the Net Generation (pp.5.1-5.16). Boulder, CO: EDUCAUSE

[69] Falcão, T. P., Flávia Mendes De Andrade E Peres, Morais, D. C., \& Oliveira, G. D. (2018). Participatory methodologies to promote student engagement in the development of educational digital games. Computers \& Education, 116, 161-175. doi:10.1016/j.compedu.2017.09.006.

[70] Taylor, L., Servage, L., McRae, P., \& Parsons, J. (2006). Alberta initiative for school improvement (AISI) collaborative professional development research review: Relationships, leadership and ownership. Edmonton, Alberta: University of Alberta \& Alberta Education. Retrieved June, 22, 2009.

[71] Dunleavy, J. \& Milton, P. (2009). What did you do in school today? Exploring the concept of Student Engagement and its implications for Teaching and Learning in Canada. Toronto: Canadian Education Association (CEA), 1-22.

[72] Heflin, H., Shewmaker, J., \& Nguyen, J. (2017). Impact of mobile technology on student attitudes, engagement, and learning. Computers \& Education, 107, 91-99. doi:10.1016/j.compedu.2017.01.006.

[73] Kvavik, R. B., Caruso, J. B., \& Morgan, G. (2004). ECAR Study of Students and Information Technology 2004: Convenience. Connection, and Control, 5 .

[74] Goyal, M., \& Krishnamurthy, R. (2018). Optimizing Student Engagement in Online Learning Environments: Intuitionistic Fuzzy Logic in Student Modeling. In Optimizing Student Engagement in Online Learning Environments (pp. 187-219). IGI Global.

[75] Russell, J. E., Van Horne, S., Ward, A. S., III, E. A. B., Sipola, M., Colombo, M., \& Rocheford, M. K. (2016). Large Lecture Transformation: Adopting Evidence-Based Practices to Increase Student 
Engagement and Performance in an Introductory Science Course. Journal of Geoscience Education, 64(1), 37-51.

[76] Wang, F. H. (2017). An exploration of online behaviour engagement and achievement in flipped classroom supported by learning management system. Computers \& Education, 114, 79-91. doi:10.1016/j.compedu.2017.06.012.

[77] Dim, L., Kim, C., \& Orey, M. (2017). Studies of student engagement in gamified online discussions. Computers \& Education, 115, 126-142. doi:10.1016/j.compedu.2017.06.016.

[78] Imlawi, J., Gregg, D., \& Karimi, J. (2015). Student engagement in course-based social networks: The impact of instructor credibility and use of communication. Computers \& Education, 88, 84-96. doi:10.1016/j.compedu.2015.04.015.

[79] Up, S. (2009). Unleashing the future: educators 'speak up'about the use of emerging technologies for learning. Recuperado el, 24.

[80] Chen, C., \& Chiu, C. (2016). Employing intergroup competition in multitouch design-based learning to foster student engagement, learning achievement, and creativity. Computers \& Education, 103, 99-113. doi:10.1016/j.compedu.2016.09.007.

[81] Zepke, N., \& Leach, L. (2010). Improving student engagement: Ten proposals for action. Active learning in higher education, 11(3), 167177.

[82] Krause, K. L., \& Coates, H. (2008). Students' engagement in first- year university. Assessment \& Evaluation in Higher Education, 33(5), 493505 .

[83] Tizzard, R. (2010, March). Strategies That Increase Student Engagement. In Society for Information Technology \& Teacher Education International Conference (Vol. 2010, No. 1, pp. 934-935).

[84] Frondeville, T. D. (2009, August 03). How to Keep Kids Engaged in Class. Retrieved June 12, 2017, from https://www.edutopia.org/ classroom-student-participation-tips.

[85] Maheady, L., \& Gard, J. (2010). Classwide peer tutoring: Practice, theory, research, and personal narrative. Intervention in School and Clinic, 46(2), 71-78.

[86] 86 Rathvon, N. (2008). Effective school interventions: Evidence-based strategies for improving student outcomes. Guilford Press.

[87] Kort, B., Reilly, R., \& Picard, R. W. (2001). An affective model of interplay between emotions and learning: Reengineering educational pedagogy-building a learning companion. Proceedings of the IEEE International Conference on Advanced Learning Technologies, Los Alamitos: CA: IEEE Computer Society Press, 43-46.

[88] Pekrun, R. (2006). The control-value theory of achievement emotions: Assumptions, corollaries, and implications for educational research and practice. Educational psychology review, 18(4), 315-341.

[89] Pekrun, R., Goetz, T., Frenzel, A. C., Barchfeld, P., \& Perry, R. P. (2011). Measuring emotions in students' learning and performance: The Achievement Emotions Questionnaire (AEQ). Contemporary educational psychology, 36(1), 36-48.

[90] Mazer, J. P. (2013). Associations among teacher communication behaviours, student interest, and engagement: A validity test. Communication Education, 62(1), 86-96.

[91] Mostafa, S. A., Darman, R., Khaleefah, S. H., Mustapha, A., Abdullah, N., \& Hafit, H. (2018, June). A General Framework for Formulating Adjustable Autonomy of Multi-agent Systems by Fuzzy Logic. In KES International Symposium on Agent and Multi-Agent Systems: Technologies and Applications (pp. 23-33). Springer, Cham.

[92] Ahmed, M., Ahmad, M. S., \& Yusoff, M. Z. M. (2010A, November). Modeling agent-based collaborative process. In International Conference on Computational Collective Intelligence (pp. 296-305). Springer, Berlin, Heidelberg.

[93] Subramainan, L., Mahmoud, M. A., Ahmad, M. S., \& Yusoff, M. Z. M. (2017, June). A simulator's specifications for studying students' engagement in a classroom. In International Symposium on Distributed Computing and Artificial Intelligence (pp. 206-214). Springer, Cham.

[94] Subramainan, L., Mahmoud, M. A., Ahmad, M. S., \& Yusoff, M. Z. M. (2016). An Emotion-based Model for Improving Students' Engagement using Agent-based Social Simulator. International Journal on Advanced Science, Engineering and Information Technology, 6(6), 952-958.

[95] Mostafa, S. A., Ahmad, M. S., Ahmad, A., \& Annamalai, M. (2013, December). Formulating situation awareness for multi-agent systems. In Advanced Computer Science Applications and Technologies (ACSAT), 2013 International Conference on(pp. 48-53). IEEE.

[96] Subramainan, L., Yusoff, M. Z. M., \& Mahmoud, M. A. (2015, August). A classification of emotions study in software agent and robotics applications research. In 2015 International Symposium on Agents, Multi-Agent Systems and Robotics (ISAMSR) (pp. 41-46). IEEE.

[97] Jassim, O. A., Mahmoud, M. A., \& Ahmad, M. S. (2015). A multi-agent framework for research supervision management. In Distributed Computing and Artificial Intelligence, 12th International Conference (pp. 129-136). Springer, Cham.

[98] Davidsson, P. (2002). Agent based social simulation: A computer science view. Journal of artificial societies and social simulation, 5(1).

[99] Mostafa, S. A., Ahmad, M. S., Ahmad, A., Annamalai, M., \& Mustapha, A. (2014). A dynamic measurement of agent autonomy in the layered adjustable autonomy model. In Recent Developments in Computational Collective Intelligence(pp. 25-35). Springer, Cham.

[100]Ahmed, M., Ahmad, M. S., \& Yusoff, M. Z. M. (2010B, June). Mitigating human-human collaboration problems using software agents. In KES International Symposium on Agent and Multi-Agent Systems: Technologies and Applications (pp. 203-212). Springer, Berlin, Heidelberg.

[101]Mostafa, S. A., Ahmad, M. S., Ahmad, A., Annamalai, M., \& Gunasekaran, S. S. (2016, August). A Flexible Human-Agent Interaction model for supervised autonomous systems. In 2016 2nd International Symposium on Agent, Multi-Agent Systems and Robotics (ISAMSR) (pp. 106-111). IEEE.

[102]Mahmoud, M. A., Ahmad, M. S., Yusoff, M. Z. M., \& Mostafa, S. A. (2018, February). A Regulative Norms Mining Algorithm for Complex Adaptive System. In International Conference on Soft Computing and Data Mining (pp. 213-224). Springer, Cham.

[103]Gilbert, N. (2008). Agent-based models (No. 153). Sage.

[104]Mahmoud, M., Ahmad, M. S., \& Yusoff, M. Z. M. (2016B). Development and implementation of a technique for norms-adaptable agents in open multi-agent communities. Journal of Systems Science and Complexity, 29(6), 1519-1537.

[105]Mostafa, S. A., Ahmad, M. S., \& Mustapha, A. (2017). Adjustable autonomy: a systematic literature review. Artificial Intelligence Review, $1-38$.

[106]Mahmoud, M. A., Mustapha, A., Ahmad, M. S., Ahmad, A., Yusoff, M. Z. M., \& Hamid, N. H. A. (2013). Potential norms detection in social agent societies. In Distributed Computing and Artificial Intelligence (pp. 419-428). Springer, Cham.

[107]Mahmoud, M. A., Ahmad, M. S., Ahmad, A., Yusoff, M. Z. M., \& Mustapha, A. (2012, June). A norms mining approach to norms detection in multi-agent systems. In 2012 International Conference on Computer \& Information Science (ICCIS) (Vol. 1, pp. 458-463). IEEE.

[108]Mahmoud, M. A., Ahmad, M. S., \& Yusoff, M. Z. M. (2016A, March). A norm assimilation approach for multi-agent systems in heterogeneous communities. In Asian Conference on Intelligent Information and Database Systems (pp. 354-363). Springer, Berlin, Heidelberg.

[109]Mahmoud, M. A., Ahmad, M. S., Yusoff, M. Z. M., \& Idrus, A. (2015). Automated multi-agent negotiation framework for the construction domain. In Distributed Computing and Artificial Intelligence, 12th International Conference (pp. 203-210). Springer, Cham. 